\title{
Oral soft-tissue sarcomas diagnosed in an oral pathology service: a 16year experience
}

\author{
- Paulo Sérgio Souza Pina Department of Stomatology, School of Dentistry, University of São Paulo (USP), São Paulo, \\ SP, Brazil • Mariana Lobo Bergamini Department of Stomatology, School of Dentistry, University of São Paulo (USP), \\ São Paulo, SP, Brazil • Fábio Luiz Coracin Department of Dentistry, Hospital de Amor de Barretos, PIO XII Foundation, \\ Barretos, SP, Brazil • Suzana C. O. M. de Sousa Department of Stomatology, School of Dentistry, University of São \\ Paulo (USP), São Paulo, SP, Brazil
}

ABSTRACT | Objective: This study analyzed the prevalence and clinic-pathological features of soft-tissue sarcomas diagnosed in a single-center of oral pathology from a School of Dentistry in Brazil. Materials and methods: All consecutive cases of intra-oral soft-tissue sarcomas diagnosed between January of 2002 and December of 2018 were retrieved from the files; patient data (sex, age and race) and characteristics of the lesions (site, size, clinical aspect and duration of injury) were collected. Results: Among a total of 62,255 biopsies diagnosed in the studied period, soft-tissue oral sarcomas comprised 76 cases (o.12\%). Kaposi sarcoma, rhabdomyosarcoma, leiomyosarcoma encompassed $64.5 \%$ of the cases, and $53 \%$ of these were diagnosed as Kaposi Sarcoma. Male patients were more affected $(59.2 \%)$ and white patients comprised $50 \%$. In general, $39.4 \%$ of the patients were between 21-40yo. Conclusion: Soft-tissue sarcomas are rare in oral soft-tissue and in our pathology service, they comprised only $0.12 \%$ of all diseases diagnosed in the studied period. Kaposi sarcoma was the most frequent, followed by leiomyosarcoma and rhabdomyosarcoma. Thus, it is important for stomatologists and pathologists to be aware of their characteristics when examining oral mucosa, mainly their peculiarities regarding patient's age, clinical appearance, and site of occurrence.

DESCRIPTORS | Sarcoma; Epidemiology; Diagnosis; Histopathology; Soft-Tissue.

RESUMO | Sarcomas de tecido mole oral diagnosticado em um serviço de patologia orai: uma experiência de 16 anos - Objetivo: Este estudo analisou a prevalência e as características clinico-patológicas de sarcomas de tecidos moles diagnosticados em um único centro de patologia oral de uma escola odontológica no Brasil. Materiais e métodos: Todos os casos consecutivos de sarcomas de tecido mole intraoral, diagnosticados entre janeiro de 2002 e dezembro de 2018, foram obtidos de arquivos; os dados dos pacientes (sexo, idade e raça) e as características da lesão (local, tamanho, aspecto clínico e duração da lesão) foram coletados. Resultado: De 62.255 biopsias diagnosticadas no período estudado, sarcoma oral de tecidos moles abrangia somente 76 dos casos (o,12\%). Desses, sarcoma de Kaposi, rabdomiossarcoma e leiomiossarcoma correspondiam a $64,5 \%$; dos quais, $53 \%$ foram diagnosticados como sarcoma de Kaposi. Pacientes masculinos foram os mais afetados $(59,2 \%)$ e $50 \%$ dos pacientes eram brancos. Em geral, 39,4\% dos pacientes tinham entre 21-40 anos de idade. Conclusão: Sarcomas de tecido mole são raros em tecido mole oral e, em nosso serviço de patolologia, totalizavam apenas $0,12 \%$ de todas as doenças diagnosticadas no período do estudo. Sarcoma de Kaposi foi o mais frequente, seguido por leiomiossarcoma e rabdomiossarcoma. Por isso é importante para estomatologistas e patologistas estarem atentos às características durante o exame da mucosa oral, principalmente às suas peculiaridades referentes à idade do paciente, a aparência clínica da lesão e o local da ocorrência.

DESCRITORES | Sarcoma; Epidemiologia; Diagnóstico; Histopatologia; Tecidos Moles.

CORRESPONDING AUTHOR | Paulo Sérgio Souza Pina Department of Stomatology, University of São Paulo - Av. Prof. Lineu Prestes, 2227 São Paulo, SP, Brasil • 05508000 E-mail: ps.souzapina@usp.br

- Received April 16, 2021 • Accepted August 10, 2021 


\section{INTRODUCTION}

Sarcomas are uncommon, malignant, and usually aggressive neoplasms that only rarely involve the oral soft-tissues. They are solid tumors of mesenchymal cells and exhibit a variety of clinical and pathologic characteristics with different prognostic implications. ${ }^{1}$ They correspond to less than $1 \%$ of all oral cancers ${ }^{2}$ and comprise only around $10 \%$ of all sarcomas of the body in adults; ${ }^{3,4}$ in children, however, $21 \%$ of all malignancies are sarcomas, ${ }^{5}$ of which $7 \%-10 \%$ affect the soft tissues. ${ }^{4,6}$ Around $87 \%$ of head and neck soft-tissue sarcomas are extragnathic, being the maxilla responsible for $8 \%$ of the cases, and the mandible, $5 \% .{ }^{4}$ Nevertheless, rhabdomyosarcomas are more frequent in the head and neck region than in any other part of the body. ${ }^{1}$

Sarcomas occur mostly in males, and the mean age of occurrence is between 50-55 years. Most oral soft-tissue sarcomas are complex, and there is a large spectrum of histopathological subtypes, what can modify the prognosis. ${ }^{3}$ In general, soft-tissue sarcomas are largely variable due to their rarity, diversity, and heterogeneity. ${ }^{2,7}$ Moreover, acquired genetic mutations and genetic predisposition, along with chemical carcinogens and viral infections, or even previous exposure to radiation or chemotherapy, play an important role in the pathogenesis of these tumours. ${ }^{4,8}$

Although imaging exams such as ultrasound and magnetic resonance are used for diagnosing soft-tissue sarcomas, biopsy is essential for tumor differentiation and grading. However, excisional biopsies must be avoided to prevent contamination of the site, and, consequently, to reduce the risk of jeopardizing the treatment and outcomes. ${ }^{4}$

The increased use of immunohistochemistry and molecular markers have improved the ability to definitively subclassify sarcomas. ${ }^{1} \mathrm{~A}$ meticulous histopathologic analysis with the use of immunohistochemistry and, sometimes, the use of molecular techniques are essential. ${ }^{9}$
The treatment of soft tissue sarcomas of the head and neck is complex, and the outcomes depend on grade, histopathological type, and extent of the tumour. ${ }^{2,4}$ Surgical resection with negative margins is the primary treatment of choice, and postoperative radiation can improve the prognosis, ${ }^{9,10}$ being mainly reserved for patients with high-grade or advanced disease. ${ }^{4}$ Although the role of chemotherapy in these lesions is not well known yet, ${ }^{9}$ this treatment is considered in cases that have a high risk of lung metastases, and when local relapse cannot be surgically salvaged. ${ }^{4,11}$ However, because of the challenges in achieving local control, the threshold for using neo-adjuvant chemotherapy in head and neck soft-tissue sarcomas may be lower than in soft tissue sarcomas of the extremities. ${ }^{2}$

Epidemiological studies based on clinical, histopathological and immunohistochemical results can contribute to determine accurate data. ${ }^{12}$ Due to the rarity of these neoplasms in the oral mucosa, this paper reports a retrospective study which analyzes the prevalence of intra oral soft-tissue sarcomas (IOSTS) in an Oral and Maxillofacial Pathology Service from a School of Dentistry in Brazil.

\section{MATERIALS AND METHODS}

A cross-sectional study was performed in the files from the Oral and Maxillofacial Pathology Department of the School of Dentistry at the University of São Paulo, São Paulo - Brazil. Cases diagnosed as intraoral soft-tissue sarcomas (IOSTS), comprising the period from January 2002 to December 2018, were reviewed. The study was performed after the approval of the local ethics committee (number 1.824.891)

Clinical aspects of the patients and of their tumors were obtained from the records of the histopathological diagnosis requirement. Patient data (sex, age, and race) and tumor data (site, clinical aspect, size, time of evolution) were collected from each case. All morphological and immunohistochemical slides were reviewed for diagnosis confirmation. The sarcomas which originated in hardtissues or cartilage were excluded. 
Analysis of global prevalence (sarcomas/total biopsies), type of sarcoma, as well as prevalence by sex, age group, and location in the mucosa were performed.

\section{RESULTS}

One-hundred and ninety-five cases (0.31\%) diagnosed as sarcomas were retrieved from a total of 62,255 biopsies diagnosed in the time ranged. Out of this total, 76 cases were diagnosed as intra oral soft-tissue sarcomas (IOSTS), with a $0.12 \%$ prevalence from 2002 to 2018. To identify whether the prevalence of the tumors changed over time we considered the periods: 2002-2003 (prevalence 0.18\%), 2004-2008 (0.14\%), 2009-2013 (0.14\%), 2014-2018 (0.05\%). All hematoxylin-eosin stained slides were reviewed by two pathologists, as well as immunohistochemical results (when available), for diagnosis accuracy. Figure 1 illustrates the most typical histological aspects of the 4 (four) most frequent intra oral soft tissue sarcomas.

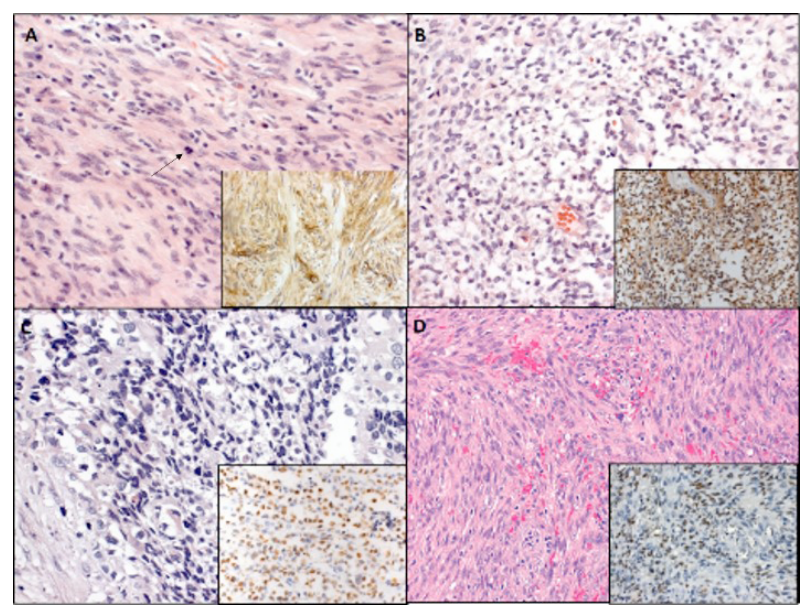

FIGURE 1 | The most typical histopathological aspect of the four most frequent oral soft tissue sarcomas - hematoxylin-eosin stain in magnification of $\times 100$ and positive immunohistochemical (inset): (A) a leiomyosarcoma showing spindle cell fascicles with abundant eosinophilic cytoplasm, no precise limits and cigar-shaped nuclei, and a mitosis (arrow). Positive for smooth muscle actin (SMA) (inset); (B) a liposarcoma depicting variable-sized lipoblasts with atypical and vacuolated cells; Inset showing positivity for S-100; (C) an alveolar rhabdomyosarcoma showing intersecting fascicles of mitotically active, large round cells with scanty cytoplasm and large nuclei. Nuclei positive for myogenin (inset); and (D) a Kaposi sarcoma which shows neoplastic proliferation of bulky spindle cells with imprecise limits and poorly formed vascular slits. Nuclei positive for HHV-8 (as seen in the inset).
IOSTS represented $2.64 \%$ of all malignant lesions diagnosed at any anatomical location in the service (2.872). Table 1 shows the demographic data of the patients. There was a predominance of males ( 45 cases, 59.2\%). Although in 22 cases the skin color was not informed, most of the patients were white ( 38 cases or $50 \%$ ), in the $3^{\text {rd }}$ or $4^{\text {th }}$ decades of life (14 and 16 patients, respectively). The mean age was $33.9 y 0$ (range: 0-71yo).

TABLE 1 | Demographic characteristics of the patients.

\begin{tabular}{l|l}
$\begin{array}{l}\text { DEMOGRAPHIC DATA } \\
\text { Gender }\end{array}$ & FREQUENCY (\%)* \\
\hline Male & $45(59.2 \%)$ \\
\hline Female & $31(40.8 \%)$ \\
\hline Race & $38(50 \%)$ \\
\hline White & $11(14.5 \%)$ \\
\hline Black & $5(6.6 \%)$ \\
\hline Mixed & $22(28.9 \%)$ \\
\hline Not informed & $10(13.2 \%)$ \\
\hline Age group (years) & $09(11.8 \%)$ \\
\hline $1-10$ & $14(18.4 \%)$ \\
\hline $11-20$ & $16(21 \%)$ \\
\hline $21-30$ & $10(13.2 \%)$ \\
\hline $31-40$ & $06(7.9 \%)$ \\
\hline $41-50$ & $07(9.2 \%)$ \\
\hline $51-60$ & $01(1.3 \%)$ \\
\hline $61-70$ & $03(3.9 \%)$ \\
\hline Not informed & \\
\hline Represents the total of all 80 cases.
\end{tabular}

The distribution of IOSTS showed that Kaposi sarcoma was the most frequent tumor, corresponding to $34.2 \%$ of all cases (26 cases), followed by leiomyosarcomas (13 cases $-17.1 \%$ ) and rhabdomyosarcomas (10 cases $13.2 \%$ ), making up $64.5 \%$ of all the cases diagnosed in the period. In addition, Kaposi sarcoma demonstrated to be more frequent in males (22/26 cases) and mostly in HIV+ patients (18/26 confirmed cases) (Table 2). Of the HIV+ patients, 4 (four) were not aware of it when the Kaposi sarcoma was diagnosed. The other patients were in antiretroviral treatment and for one patient the lesion was a recurrence. 
TABLE 2 | Histological type of oral soft-tissue sarcomas and gender distribution.

\begin{tabular}{|c|c|c|c|}
\hline \multirow[t]{2}{*}{ TUMOUR TYPE } & \multicolumn{3}{|c|}{ SEX } \\
\hline & Male & Female & Total (Frequency - \%)* \\
\hline Kaposi sarcoma & 22 & 4 & $26(34.2 \%)$ \\
\hline Leiomyosarcoma & 7 & 6 & 13 (17.1\%) \\
\hline Rhabdomyosarcoma & 5 & 5 & $10(13.2 \%)$ \\
\hline Malignant schwannoma & 3 & 2 & $5(6.6 \%)$ \\
\hline Liposarcoma & 1 & 3 & $4(5.3 \%)$ \\
\hline Myxoid sarcoma & 2 & 2 & $4(5.3 \%)$ \\
\hline Synovial sarcoma & 1 & 1 & $2(2.6 \%)$ \\
\hline High-grade sarcoma & 1 & 1 & $2(2.6 \%)$ \\
\hline Spindle cell sarcoma & 0 & 2 & $2(2.6 \%)$ \\
\hline Alveolar sarcoma & 0 & 2 & $2(2.6 \%)$ \\
\hline Carcinosarcoma & 1 & 0 & $1(1.3 \%)$ \\
\hline Hystocitic sarcoma & 0 & 1 & $1(1.3 \%)$ \\
\hline Dendritic cells sarcoma & 0 & 1 & $1(1.3 \%)$ \\
\hline Undifferentiated sarcoma & 1 & 0 & $1(1.3 \%)$ \\
\hline Pleomorphic sarcoma & 1 & 0 & $1(1.3 \%)$ \\
\hline Myofibroblastic sarcoma & 0 & 1 & $1(1.3 \%)$ \\
\hline TOTAL & 45 & 31 & $76(100 \%)$ \\
\hline
\end{tabular}

* Represents the total of all 80 cases.

While rhabdomyosarcoma was the most common histopathological type seen in pediatric patients (5 cases - 50\%), Kaposi sarcoma was frequently diagnosed in adults in the third (10 cases $-38.46 \%$ ) and fourth (9 cases $-34.61 \%$ ) decades of life. The palate was the most common primary affected site (24 cases, $31.6 \%$ ), followed by gingiva (11 cases $-14.5 \%$ ), buccal mucosa ( 9 cases $-11.8 \%$ ), tongue ( 8 cases $-10.5 \%$ ), upper and lower alveolar ridge (6 cases $-7.9 \%)$. Other locations of involvement were lips, floor of mouth, upper buccal vestibule, retromolar region, soft palate, and peri-implant mucosa. In six cases there was no site of involvement registered (Table 3). Figure 2 illustrates both clinical and histological appearance of a rare synovial sarcoma located in retromolar area.

Table 4 shows that clinical presentation varied between a nodule or a solid mass (28 cases, $36.8 \%$ ), followed by ulcer (4 cases $-5.3 \%$ ) and maculae ( 3 cases $-3.9 \%$ ) and, in 19 cases (25\%), the patients stated that the lesions were asymptomatic.

TABLE 3 | Distribution of oral soft-tissue sarcomas and their main site of location.

\begin{tabular}{|c|c|c|c|c|c|c|c|}
\hline \multirow{2}{*}{ TUMOUR TYPE } & \multicolumn{6}{|c|}{ LOCATION } & \multirow{2}{*}{ NI } \\
\hline & Palate & Gingiva & Buccal mucosa & Tongue & Alveolar ridge & Others & \\
\hline Kaposi sarcoma & 14 & 3 & 0 & 2 & 1 & 5 & 2 \\
\hline Leiomyosarcoma & 5 & 1 & 2 & 2 & 1 & 2 & 0 \\
\hline Rhabdomyosarcoma & 1 & 1 & 3 & 0 & 1 & 3 & 1 \\
\hline Liposarcoma & 0 & 0 & 1 & 2 & 0 & 0 & 1 \\
\hline Malignant schwannoma & 2 & 2 & 1 & 0 & 0 & 0 & 0 \\
\hline
\end{tabular}


TABLE 3 | Continuation

\begin{tabular}{|c|c|c|c|c|c|c|c|}
\hline \multirow{2}{*}{ TUMOUR TYPE } & \multicolumn{6}{|c|}{ LOCATION } & \multirow{2}{*}{ NI } \\
\hline & Palate & Gingiva & Buccal mucosa & Tongue & Alveolar ridge & Others & \\
\hline Myxoid sarcoma & 0 & 1 & 0 & 0 & 0 & 1 & 2 \\
\hline Synovial sarcoma & 0 & 1 & 1 & 0 & 0 & 0 & 0 \\
\hline High-grade sarcoma & 0 & 1 & 0 & 0 & 1 & 0 & 0 \\
\hline Spindle cell sarcoma & 2 & 0 & 0 & 0 & 0 & 0 & 0 \\
\hline Alveolar sarcoma & 0 & 0 & 0 & 2 & 0 & 0 & 0 \\
\hline Carcinosarcoma & 0 & 0 & 0 & 0 & 0 & 1 & 0 \\
\hline Histiocytic sarcoma & 0 & 1 & 0 & 0 & 0 & 0 & 0 \\
\hline Dendritic cells sarcoma & 0 & 0 & 0 & 0 & 1 & 0 & 0 \\
\hline Undifferentiated sarcoma & 0 & 0 & 0 & 1 & 0 & 0 & 0 \\
\hline Pleomorphic sarcoma & 0 & 0 & 1 & 0 & 0 & 0 & 0 \\
\hline Myofibroblastic sarcoma & 0 & 1 & 0 & 0 & 0 & 0 & 0 \\
\hline Total (n)/Frequency (\%) & $24(31.6 \%)$ & $11(14.5 \%)$ & $9(11.8 \%)$ & $8(10.5 \% ")$ & $6(7.9 \%)$ & $12(15.8 \%)$ & $6(7.9 \%)$ \\
\hline
\end{tabular}

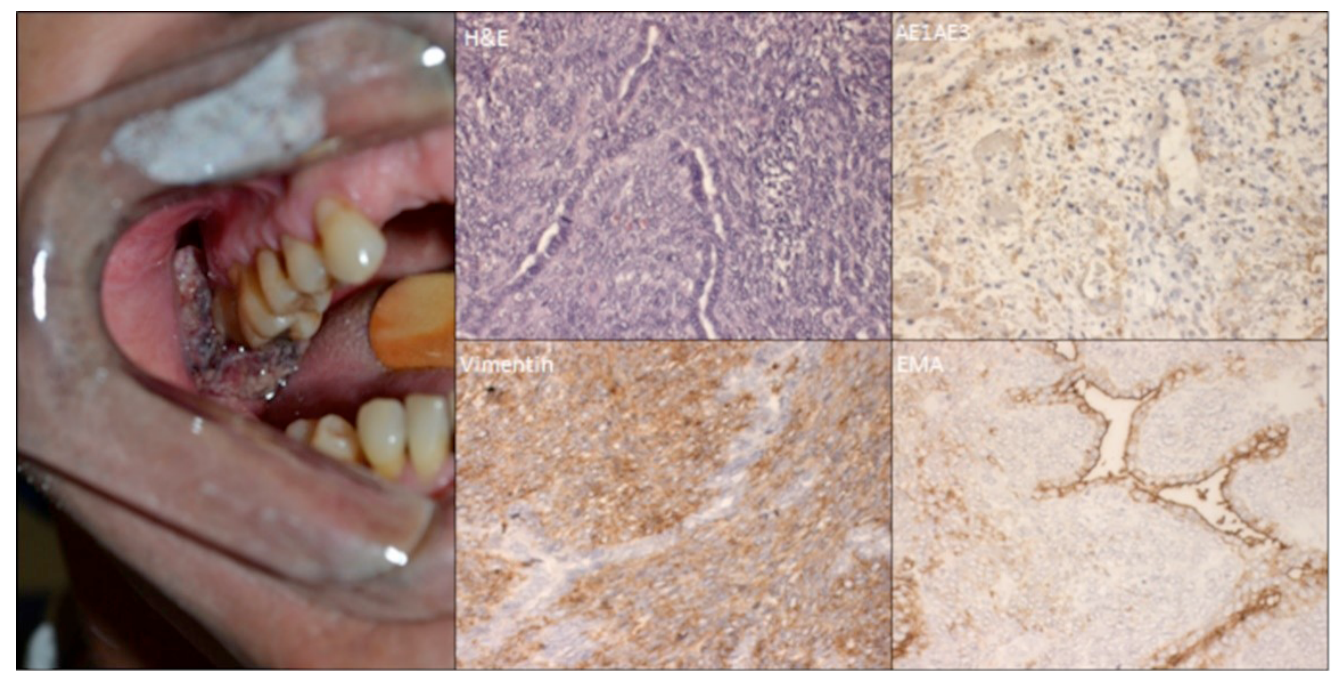

FIGURE 2 | A case of synovial sarcoma occurring in a 52 years old White man, smoker and alcoholic with a heterogenous and ulcerated tumor of the gingiva in the retromolar area (A); neoplastic spindle and epithelial cell proliferation, with predominance of spindle cell (B); positive immunohistochemical reaction for AE1AE3 (C); vimentin (D); and EMA (E).

TABLE 4 | Fundamental lesion distribution and symptomatology of oral soft-tissue sarcomas.

\begin{tabular}{c|c}
\hline Main lesion & Frequency (\%) \\
\hline Nodule (or solid mass) & $28(36.8 \%)$ \\
\hline Ulcer & $4(5.3 \%)$ \\
\hline Macula & $3(3.9 \%)$ \\
\hline Tumor & $1(1.3 \%)$ \\
\hline Plaque & $1(1.3 \%)$ \\
\hline Not informed & $39(51.3 \%)$ \\
\hline
\end{tabular}

\section{DISCUSSION}

Oral soft-tissue sarcomas are rare mesenchymal neoplasms that comprise only $1 \%$ of all malignant neoplasms. ${ }^{13-20}$ Most published papers refer to no more than 40 cases in a single center, but we retrospectively retrieved 76 cases of soft-tissue sarcomas in oral mucosa in an Oral and Maxillofacial Pathology single center.

These tumors rarely manifest in the head and neck, except in pediatric population. In general, they represent $2-15 \%$ of all sarcomas in adults, and less than $1 \%$ of all malignant neoplasms originating in the oral cavity are sarcomas. ${ }^{13-20}$ According to the World Health Organization (WHO), there are over fifty subtypes of sarcomas ${ }^{10,17}$ coming from 
all mesenchymal tissues including bone, cartilage, muscle, fibrous, vascular, fat, and neural. ${ }^{16}$ The classification proposed by WHO in 2002 include neoplasms with the same cellular differentiation, which is determined mainly by morphologic and immunohistochemical features. ${ }^{10}$

In this study we focused only on IOSTS. Few studies in the literature have focused on oral sarcomas ${ }^{21}$ since most authors include them in head and neck tumors, as a whole. Therefore, the prevalence of types of sarcomas that we found is different from others that include all head and neck sites. ${ }^{22,23}$ Sumida et al. ${ }^{20}$ analyzed 19 cases of these lesions and observed that only 12 of them originated from soft tissues. In our study, oral soft tissue sarcomas totalized 76 out of 191 intraoral sarcomas. Considering the total of biopsies diagnosed at our service, oral soft-tissue sarcomas represented less than $1 \%$. When analyzed, the prevalence over time (2002-2003, 2004-2008, 2009-2013, 2014-2018) showed that the frequency of cases in each period did not reach $1 \%$, corroborating with previous studies found in the literature..$^{13,15}$ Furthermore, the prevalence of IOSTS between 20142018 (0.05\%) was the lowest registered in four years, likely due to the decrease of Kaposi sarcoma cases.

Among our cases, Kaposi sarcoma was the most frequent. This finding is different from other research in which rhabdomyosarcomas and leiomyosarcomas were the most frequent lesions. ${ }^{19,22-24}$ However, as commented above, those studies considered all head and neck sites. Carvalho et al. ${ }^{12}$ analyzed the frequency of oral sarcomas in 12 representative oral and maxillofacial pathology centers, and they found that Kaposi sarcoma was the main soft-tissue sarcoma of the oral cavity followed by leiomyosarcoma, which is consistent with our findings.

Soft-tissue sarcomas arising in oral mucosa can occur at any age group, however it was observed that, in general, intraoral sarcomas manifest mostly in young people..$^{21,25}$ In our study, the mean age at diagnosis was 33.9 years (range: $0-71$ years) and the first decades of life were more affected. A similar age distribution was seen in a series of studies. ${ }^{21,22,25}$ Nevertheless, Woods et al. ${ }^{26}$ observed that the incidence of oral soft-tissue sarcomas increased, significantly, with age. It is worth pointing out that in the study by Woods et al., soft-tissue sarcomas from the whole body were analyzed, unlike the present study which focused only on the oral tissues.

The fact that these neoplasms affect more men than women is well elucidated in the literature. In the United States, South Africa, and in many European countries, homosexual and bisexual men have a higher risk of developing Kaposi sarcoma associated with AIDS, ${ }^{27-29}$ as also found in the present casuistic.

Due to the insidious clinical presentation, early diagnosis of sarcoma is a challenge. Many symptoms can be observed, such as a growing mass with or without the presence of pain, teeth with mobility, nodular vascular lesions, voice change, dysphagia, or odynophagia. When faced with these symptoms, a suspicion of sarcoma should be raised and referred urgently. ${ }^{4,11,30}$

Leiomyosarcoma was the second most common mesenchymal neoplasm, followed by rhabdomyosarcoma, liposarcoma, and myxoid sarcoma. Differently, Chidzonga and Mahomva ${ }^{23}$ observed that leiomyosarcomas comprised the fourth most common sarcoma with a 5:1 male:female ratio, however, it is important to note that, their analysis was not restricted to soft-tissue sarcomas. The distribution of sarcomas according to the age showed that Kaposi sarcoma and leiomyosarcoma were prevalent in the third and fourth decades, while rhabdomyosarcoma was more frequent in children and adolescents. The ages ranged from 4 to 55 years for Kaposi sarcoma, 12 to 70 years for leiomyosarcoma, and o to 57 years for rhabdomyosarcoma.

Rhabdomyosarcoma was the third most frequent tumor in our review. It is the most common pediatric soft-tissue sarcoma, affecting the head and neck region in $35 \%$ of cases. ${ }^{31,32}$ They usually manifest as rapidly growing masses and, depending on the 
location, may be asymptomatic, show paresthesia, trismus, facial paralysis, or nasal secretion. ${ }^{33}$ Our findings revealed that children and adolescents were the most affected, being more prevalent in the first and second decades of life, with no predilection for gender. Similarly, Chidzonga and Mahomva, ${ }^{23}$ when reviewing 88 cases of head and neck sarcomas, noted that rhabdomyosarcoma was the second most frequent neoplasm, usually under the age of 10 years. Yamaguchi et al. ${ }^{16}$ observed rhabdomyosarcoma as the third most common histological type from a review of 32 cases of sarcomas, in general.

Palate was the most affected location when compared to gingiva, tongue, and buccal mucosa; being Kaposi's sarcoma responsible for 14 out of 26 cases on this site. Other studies also showed this predilection for the palate, followed by gingiva. ${ }^{12,34}$ Kaposi sarcoma of the oral mucosa may be indolent or sudden and fulminant. They are manifested as unifocal or multifocal lesions and their clinical presentation can be as macules, papules, nodules, or exophytic masses, which can become ulcerated. This latter form of presentation has a higher HHV8 load than early maculopapular lesions. . $^{34,35}$ In our study, 9 out of 26 Kaposi sarcomas were asymptomatic.

Jaws appear to be the site of predilection for oral leiomyosarcomas, and approximately $50 \%$ of these tumors arise in the maxilla and mandible. ${ }^{36}$ Our findings showed palate involvement in 5 out of 13 leiomyosarcomas. Other reported intraoral sites included soft palate, lips, buccal mucosa, tongue, floor of mouth and gingiva. ${ }^{3-38}$

\section{CONCLUSIONS}

Since all cases in this study were diagnosed using HE staining and conventional immunohistochemistry, we may conclude that morphological features still play an important role in the diagnostic approach of these lesions. Moreover, these tumors seem to affect mainly male and younger patients. Kaposi sarcoma was the most frequent lesion.

\section{DECLARATIONS}

Conflicts of interest: The authors declare that they have no conflicts of interest to disclose.

Funding: Not applicable.

\section{REFERENCES}

1. O’Neill JP, Bilsky MH, Kraus D. Head and neck sarcomas: epidemiology, pathology, and management. Neurosurg Clin NAm. 2013;24:67-78. Doi: https://doi.org/10.1016/j.nec.2012.08.010

2. Vassiliou LV, Lalabekyan B, Jay A, Liew C, Whelan J, Newman L, et al. Head and neck sarcomas: a single institute series. Oral Oncol. 2017;65:16-22. Doi: https://doi.org/10.1016/j. oraloncology.2016.12.005

3. Mendenhall WM, Mendenhall CM, Werning JW, Riggs CE, Mendenhall NP. Adult head and neck soft tissue sarcomas. Head Neck. 2005;27(10):916-22. Doi: https://doi. org/10.1002/hed.20249

4. Kalavrezos N, Sinha D. Head and neck sarcomas in adulthood: current trends and evolving management concepts. Br J Oral Maxillofac Surg. 2020;58(8):890-7. Doi: https:// doi.org/10.1016/j.bjoms.2020.05.015

5. Burningham Z, Hashibe M, Spector L, Schiffman JD. The epidemiology of sarcoma. Clin Sarcoma Res. 2012;2:14. Doi: https://doi.org/10.1186/2045-3329-2-14

6. Birch JM, Alston RD, Quinn M, Kelsey AM. Incidence of malignant disease by morphological type, in young persons aged 1224 years in England,1979-1997. Eur J Cancer. 2003;39(18):262231. Doi: https://doi.org/10.1016/j.ejca.2003.08.006

7. Patel SG, Shaha AR, Shah JP. Soft tissue sarcomas of the head and neck: an update. Am J Otolaryngol. 2001;22(1):2-18. Doi: https://doi.org/10.1053/ajot.2001.20699

8. Mortus JR, Zhang Y, Hughes DP. Developmental pathways hijacked by osteosarcoma. Adv Exp Med Biol. 2014;804:93118. Doi: https://doi.org/10.1007/978-3-319-04843-7_5

9. Galy-Bernadoy C, Garrel R. Head and neck soft-tissue sarcoma in adults. Eur Ann Otorhinolaryngol Head Neck Dis. 2016;133(1):37-42. Doi: https://doi.org/10.1016/j.anorl.2015.09.003

10. Rastatter JC, Sinard RN, Dilger A, Reichek J, Walterhouse DO, Patel U. Survival of patients with non-rhabdomyosarcoma soft tissue sarcomas of the head and neck. Laryngoscope. 2020;131(2):E500-8. Doi: https://doi.org/10.1002/lary.28789

11. Dangoor A, Seddon B, Gerrand C, Grimer R, Whelan J, Judson I. UK guidelines for the management of soft tissue 
sarcomas. Clin Sarcoma Res. 2016;6:20. Doi: https://doi. org/10.1186/s13569-016-006o-4

12. Carvalho WRS, Souza LL, Pontes FSC, Uchôa DCC, Corrêa DL, Cáceres CVBL, et al. A multicenter study of oral sarcomas in Brazil. Oral Dis. 2020;26(1):43-52. Doi: https://doi. org/10.1111/odi.13211

13. Wanebo HJ, Koness RJ, MacFarlane JK, Eilber FR, Byers RM, Elias EG, et al. Head and neck sarcoma: report of the Head and Neck Sarcoma Registry. Head Neck. 1992;14(1):1-7. Doi: https://doi.org/10.1002/hed.2880140102

14. Kraus DH. Sarcomas of the head and neck. Curr Oncol Rep. 2002;4:68-75. Doi: https://doi.org/10.1007/s11912-002-0050-y

15. Zagars GK, Ballo MT, Pisters PW, Pollock RE, Patel SR, Benjamin RS, et al. Prognostic factors for patients with localized soft-tissue sarcoma treated with conservation surgery and radiation therapy: an analysis of 1225 patients. Cancer. 2003;97(10):2530-43. Doi: https://doi.org/10.1002/cncr.11365

16. Yamaguchi S, Nagasawa H, Suzuki T, Fujii E, Iwaki H, Takagi M, et al. Sarcomas of the oral and maxillofacial region: a review of 32 cases in 25 years. Clin Oral Investig. 2004;8:52-5. Doi: https://doi.org/10.1007/so0784-003-0233-4

17. Singh RP, Grimer RJ, Bhujel N, Carter SR, Tillman RM, Abu$\mathrm{du}$ A. Adult head and neck soft tissue sarcomas: treatment and outcome. Sarcoma. 2008;2008:654987. Doi: https://doi. org/10.1155/2008/654987

18. de Bree R, van der Waal I, de Bree E, Leemans CR. Management of adult soft tissue sarcomas of the head and neck. Oral Oncol. 2010;46(11):786-90. Doi: https://doi.org/10.1016/j.oraloncology.2010.09.001

19. Huber GF, Matthews TW, Dort JC. Soft-tissue sarcomas of the head and neck: a retrospective analysis of the Alberta Experience 1974 to 1999. Laryngoscope. 2006;116(5):780-5. Doi: https://doi.org/10.1097/01.MLG.0000206126.48315.85

20. Sumida T, Otawa N, Kamata YU, Yamada T, Uchida K, Nakano $\mathrm{H}$, et al. A clinical investigation of oral sarcomas at multi-institutions over the past 30 years. Anticancer Res. 2015;35(8):4551-5.

21. Gorsky M, Epstein JB. Head and neck and intra-oral soft tissue sarcoma. Oral Oncol. 1998;34(4):292-6. Doi: https:// doi.org/10.1016/S1368-8375(98)80010-9

22. Pandey M, Thomas G, Mathew A, Abraham EK, Somanathan $\mathrm{T}$, Ramadas K, et al. Sarcoma of the oral and maxillofacial soft tissue in adults. Eur J Surg Oncol. 2000;26(2):145-8. Doi: https://doi.org/10.1053/ejso.1999.0758

23. Chidzonga MM, Mahomva L. Sarcomas of the oral and maxillofacial region: a review of 88 cases in Zimbabwe. $\mathrm{Br}$
J Oral Maxillofac Surg. 2007;45(4):317-8. Doi: https://doi. org/10.1016/j.bjoms.2005.11.008

24. Weber RS, Benjamin RS, Peters LJ, Ro JY, Achon O, Goepfert H. Soft tissue sarcomas of the head and neck in adolescents and adults. Am J Surg. 1986;152(4):386-92. Doi: https://doi. org/10.1016/0002-9610(86)90309-0

25. Eeles RA, Fisher C, A'Hern RP, Robinson M, Rhys-Evans P, Henk JM, et al. Head and neck sarcomas: prognostic factors and implications for treatment. Br J Cancer. 1993;68:201-7. Doi: https://doi.org/10.1038/bjc.1993.314

26. Woods RH, Potter JA, Reid JL, Louise J, Bessen T, Farshid G, et al. Patterns of head and neck sarcoma in Australia. ANZ J Surg. 2018;88(9):901-6. Doi: https://doi.org/10.1111/ans.14018

27. Flaitz CM, Nichols CM, Hicks MJ. An overview of the oral manifestations of AIDS-related Kaposi's sarcoma. Compend Contin Educ Dent. 1995;16(2):136-8.

28. Lundgren JD, Melbye M, Pedersen C, Rosenberg PS, Gerstoft J. Changing patterns of Kaposi's sarcoma in Danish acquired immunodeficiency syndrome patients with complete follow-up. Am J Epidemiol. 1995;141(7):652-8. Doi: https:// doi.org/10.1093/oxfordjournals.aje.a117481

29. Lager I, Altini M, Coleman H, Ali H. Oral Kaposi’s sarcoma: a clinicopathologic study from South Africa. Oral Surg Oral Med Oral Pathol Oral Radiol Endod. 2003;96(6):701-10. Doi: https://doi.org/10.1016/S1079-2104(03)00370-6

30. Gerrand C, Athanasou N, Brennan B, Grimer R, Judson I, Morland B, et al. UK guidelines for the management of bone sarcomas. Clin Sarcoma Res. 2016;6:7. Doi: https://doi. org/10.1186/s13569-016-0047-1

31. Daya H, Chan HS, Sirkin W, Forte V. Pediatric rhabdomyosarcoma of the head and neck: is there a place for surgical management? Arch Otolaryngol Head Neck Surg. 2000;126(4):468-72. Doi: https://doi.org/10.1001/archotol.126.4.468

32. Meza JL, Anderson J, Pappo AS, Meyer WH. Analysis of prognostic factors in patients with nonmetastatic rhabdomyosarcoma treated on intergroup rhabdomyosarcoma studies III and IV: The Children's Oncology Group. J Clin Oncol. 2006;24(24):384451. Doi: https://doi.org/10.1200/JCO.2005.05.3801

33. Miloglu O, Altas SS, Buyukkurt MC, Erdemci B, Altun O. Rhabdomyosarcoma of the oral cavity: a case report. Eur J Dent. 2011;5(3):340-3.

34. Pantanowitz L, Khammissa RA, Lemmer J, Feller L. Oral HIVassociated Kaposi sarcoma. J Oral Pathol Med. 2013;42(3):2017. Doi: https://doi.org/10.1111/j.1600-0714.2012.01180.x

35. PakF, MwakigonjaAR, Kokhaei P, Hosseinzadeh N, Pyakurel P, Kaaya E, et al. Kaposi's sarcoma herpesvirus load in biopsies of cutane- 
Pina PSS • Bergamini ML • Coracin FL • Sousa SCOM

ous and oral Kaposi's sarcoma lesions. Eur J Cancer. 2007;43 (12):1877-82. Doi: https://doi.org/10.1016/j.ejca.2007.05.023 36. Nikitakis NG, Lopes MA, Bailey JS, Blanchaert RH Jr, Ord RA, Sauk JJ. Oral leiomyosarcoma: review of the literature and report of two cases with assessment of the prognostic and diagnostic significance of immunohistochemical and molecular markers. Oral Oncol. 2002;38(2):201-8. Doi: https:// doi.org/10.1016/s1368-8375(01)0oo47-1
37. Karlis V, Zaslow M, Minkowitz G, Glickman RS. Leiomyosarcoma of the mandible: report of a case and literature review. J Oral Maxillofac Surg. 1996;54(9):1127-30. Doi: https://doi. org/10.1016/So278-2391(96)90176-7

38. Dry SM, Jorgensen JL, Fletcher CD. Leiomyosarcomas of the oral cavity: an unusual topographic subset easily mistaken for nonmesenchymal tumours. Histopathology. 2000;36(3):21020. Doi: https://doi.org/10.1046/j.1365-2559.2000.00814.x 